\title{
EVALUASI METODE BALANCED SCORECARD DALAM UPAYA MENILAI KINERJA KEUANGAN PT. SUMBER ALFARIA TRIJAYA, Tbk TANGERANG
}

\author{
Neneng Widayati \\ Tafrikhatun Khasanah \\ nwidayati@unis.ac.id \\ Program Studi Akuntansi \\ Fakultas Ekonomi dan Bisnis \\ Universitas Islam Syekh Yusuf Tangerang
}

\begin{abstract}
ABSTRAK
Penelitian ini bertujuan untuk mengetahui kinerja perusahaan dari segi kinerja finansial dan nonfinansial dengan menggunakan metode Balanced Scorecard melalui empat perspektif yaitu : perspektif keuangan, perspektif pelanggan, perspektif proses bisnis internal, dan perspektif pertumbuhan dan pembelajaran. Metode penelitian yang dipakai Evaluasi deskriptif kuantitatif. Hasil penelitian ini diketahui bahwa kinerja dari PT. Sumber Alfaria Trijaya Tbk, Tangerang kurang baik. Dari segi keuangan terlihat bahwa aktiva yang digunakan untuk operasi perusahaan mengalami penurunan pada tiap tahunnya. Pada perspektif pelanggan menunjukkan pendapatan bersih mengalami kenaikan tiap tahunnya tetapi laba bersihnya selalu mengalami penurunan, sehingga mengakibatkan profitabilitas pelanggannya menurun. Pada perspektif proses bisnis internal, beban operasional tiap tahunnya mengalami penurunan dan kenaikan, tetapi karena pendapatan operasional yang naik terus berdampak pada keberhasilan dalam efesiensi biaya operasional tersebut. Perspektif Pembelajaran dan Pertumbuhan, perusahaan selalu mengalami penurunan dalam tingkat produktivitas karyawan disetiap tahunnya dikarenakan selalu ada kenaikan jumlah karyawan sedangkan tidak bisa diimbangi dengan kenaikan laba perusahan.
\end{abstract}

\section{Kata kunci: Kinerja perusahaan, Balanced Scorecard}




\section{PENDAHULUAN}

\section{A. Latar Belakang Masalah}

Era saat ini, penilaian kinerja perusahaan menjadi hal yang sangat penting bagi manajemen dalam mengevaluasi kinerja dan perencanaan untuk tujuan di masa yang akan datang. Informasi mengenai kinerja perusahaan dapat diperoleh dari dua sumber, yaitu dalam segi informasi finansial dan informasi nonfinansial. Informasi finansial diperoleh dari data penjualan dan penyusunan anggaran untuk menekan biaya, sedangkan informasi nonfinansial diperoleh dari penetapan strategi yang dilakukan perusahaan.

Selama ini banyak perusahaan menggunakan pengukuran kinerja dengan menitikberatkan hanya pada sektor finansial saja, yang mengakibatkan perusahaaan hanya berpatok pada keuntungan jangka pendek tanpa memikirkan kelangsungan hidup perusahaan di masa yang akan datang. Pengukuran kinerja ini juga memiliki dampak lain karena tidak dapat mengukur kinerja harta tak berwujud dan harta intelektual perusahaan (sumber daya manusia). Selain itu pengukuran kinerja dengan cara ini juga kurang mampu bercerita banyak mengenai masa lalu perusahaan, kurang memperhatikan sektor eksternal, serta tidak mampu sepenuhnya menuntun perusahaan ke arah yang lebih baik.

Penelitian yang dilakukan oleh Kaplan dan Norton pada tahun 1990 yaitu tentang "Pengukuran Kinerja Organisasi Masa Depan". Penelitian tersebut berkaitan dengan kinerja perusahaan secara keseluruhan. Penelitian ini didorong oleh kesadaran dimana pada saat itu ukuran kinerja keuangan yang digunakan oleh semua perusahaan untuk mengukur kinerja eksekutif tidak lagi memadai. Hasil penelitian menyebutkan bahwa untuk mengukur kinerja eksekutif di masa depan diperlukan ukuran komprehensif yang meliputi empat perspektif, yaitu perspektif keuangan, perspektif pelanggan, perspektif bisnis internal, serta perspektif pertumbuhan dan pembelajaran, yang disebut dengan Balanced Scorecard. 
Balanced Scorecard digunakan untuk menyeimbangkan usaha dan perhatian eksekutif baik kinerja keuangan dan non keuangan, serta kinerja jangka pendek dan kinerja jangka panjang. Percobaan penggunaan Balanced Scorecard diperkenalkan pertama kali oleh Robert S. Kaplan dan David P. Norton sekitar satu dekade yang lalu dalam jurnal Harvard Business Review.

Balanced Scorecard menggambarkan adanya keseimbangan antara tujuan jangka pendek dan tujuan jangka panjang, antara ukuran keuangan dan nonkeuangan, antara indicator lagging dan indicator leading. Balanced Scorecard cukup komprehensif untuk memotivasi eksekutif dalam mewujudkan kinerja dalam keempat perspektif tersebut, agar keberhasilan keuangan yang dihasilkan bersifat berkesinambungan.

PT. Sumber Alfaria Trijaya Tbk, atau sering disebut toko Alfamart merupakan jaringan toko retail yang memiliki lebih dari 5000 gerai dan cabang atau distribution center (dc) di Indonesia setidaknya ada 32 cabang. Gerai ini umumnya menjual berbagai produk makanan, minuman dan kebutuhan hidup lainnya. PT. Sumber Alfaria Trijaya, Tbk selama ini menggunakan penilaian kinerja perusahaan yang lebih menitikberatkan pada sektor keuangan dan lebih memperhatikan hasil akhir (outcome) termasuk dalam hal penentuan reward ke karyawan namun kurang memperhatikan faktor-faktor penentu akhir. Perusahaan yang lebih memperhatikan hasil akhir dalam hal ini adalah hasil penjualan dan laba perusahaan tanpa memperhatikan faktor-faktor yang menjadi penentu akan menyebabkan perusahaan mengabaikan dampak yang akan timbul dalam jangka panjang.

\section{B. Perumusan Masalah}

Bertitik tolak dari Latar Belakang Masalah, maka Rumusan Masalah dalam penelitian ini adalah: "Bagaimana kinerja keuangan PT. Sumber Alfaria Trijaya, Tbk jika menggunakan metode Balanced Scorecard?" 


\section{Tujuan dan Manfaat Penelitian}

\section{Tujuan Penelitian}

Tujuan dalam penelitian ini adalah: untuk mengetahui kinerja keuangan PT. Sumber Alfaria Trijaya Tbk, jika menggunakan konsep Balanced Scorecard yang meliputi: perspektif keuangan, perspektif pelanggan, perspektif bisnis internal, serta perspektif pembelajaran dan pertumbuhan.

\section{Manfaat Penelitian}

Penelitian dilakukan dengan harapan akan memberikan suatu manfaat kepada berbagai pihak yang membacanya, yaitu sebagai berikut:

a. Dapat menambah ilmu pengetahuan dan pengalaman di dunia bisnis retail yang sesungguhnya, dan sebagai penerapan teori yang telah diperoleh selama masa perkuliahan.

b. Dapat digunakan sebagai bahan masukan agar menggunakan metode Balanced Scorecard sehingga PT. Sumber Alfaria Trijaya Tbk, dapat mengevaluasi kinerja keuangannya secara lebih komperhensif.

c. Dapat memperoleh wawasan, informasi dan pengetahuan tentang bagaimana cara mengetahui kinerja keuangan menggunakan konsep Balanced Scorecard.

\section{KAJIAN TEORITIS DAN KERANGKA PEMIKIRAN}

\section{A. Kajian Teoritis}

\section{Pengertian Kinerja Keuangan}

Menurut Fahmi (2012:2) Kinerja keuangan merupakan gambaran dari pencapaian keberhasilan perusahaan dapat diartikan sebagai hasil yang telah dicapai atas berbagai aktivitas yang telah dilakukan. Dapat dijelaskan bahwa kinerja keuangan adalah suatu analisis yang dilakukan untuk melihat sejauh mana suatu perusahaan telah melaksanakan dengan menggunakan aturan-aturan pelaksanaan keuangan secara baik dan benar.uangan suatu perusahaan dapat dinilai dengan menggunakan alat analisis. 
Sedangkan menurut Jumingan (2011:239) kinerja keuangan merupakan gambaran kondisi keuangan pada suatu periode tertentu baik menyangkut aspek penghimpunan dana maupun penyaluran dana yang biasanya diukur dengan indikator kecukupan modal, likuiditas, dan profitabilitas.

Dari pendapat para ahli dapat disimpulkan bahwa kinerja keuangan merupakan pencapaian prestasi perusahaan pada suatu periode yang menggambarkan kondisi kesehatan keuangan perusahaan dengan indikator kecukupan modal, likuiditas dan profitabilitas.

\section{Pengertian Balanced Scorecard (BSC)}

Balance Scorecard (BSC) merupakan konsep manajemen yang mencoba mengukur kinerja organisasi secara seimbang dari berbagai perspektif dengan fokus pada keberhasilan implementasi strategi organisasi (Dadang Dally 2010).

Menurut para ahli Balanced Scorecard:

a. Menurut Kaplan dan Norton (1996) Balanced Scorecard adalah seperangkat tindakan yang memberi para manajer puncak pandangan yang cepat namun komprehensif tentang bisnis mencakup langkah-langkah finansial yang memberi tahu hasil tindakan yang telah dilakukan melengkapi ukuran keuangan dengan ukuran operasional mengenai kepuasan pelanggan, proses internal, dan inovasi dan peningkatan organisasi, kegiatan-tindakan operasional yang menjadi pendorong kinerja keuangan masa depan.

b. Menurut Anthony dan Govindrajan (1997) dalam buku Management Control System. Balance Scorecard adalah suatu alat sistyem untuk memfokuskan perusahaan, meningkatkan komunikasi antar tingkatan manajemen, menentukan tujuan organisasi dan memberi umpan balik yang terus-menerus guna keputusan yang strategis.

Dari pendapat para ahli maka dapat diartikan Balanced Scorecard merupakan suatu sistem manajemen, pengukuran, dan pengendalian yang secara cepat, tepat, dan komprehensif yang dapat memberikan pemahaman kepada manajer tentang performance bisnis 


\section{B. Kerangka Pemikiran}

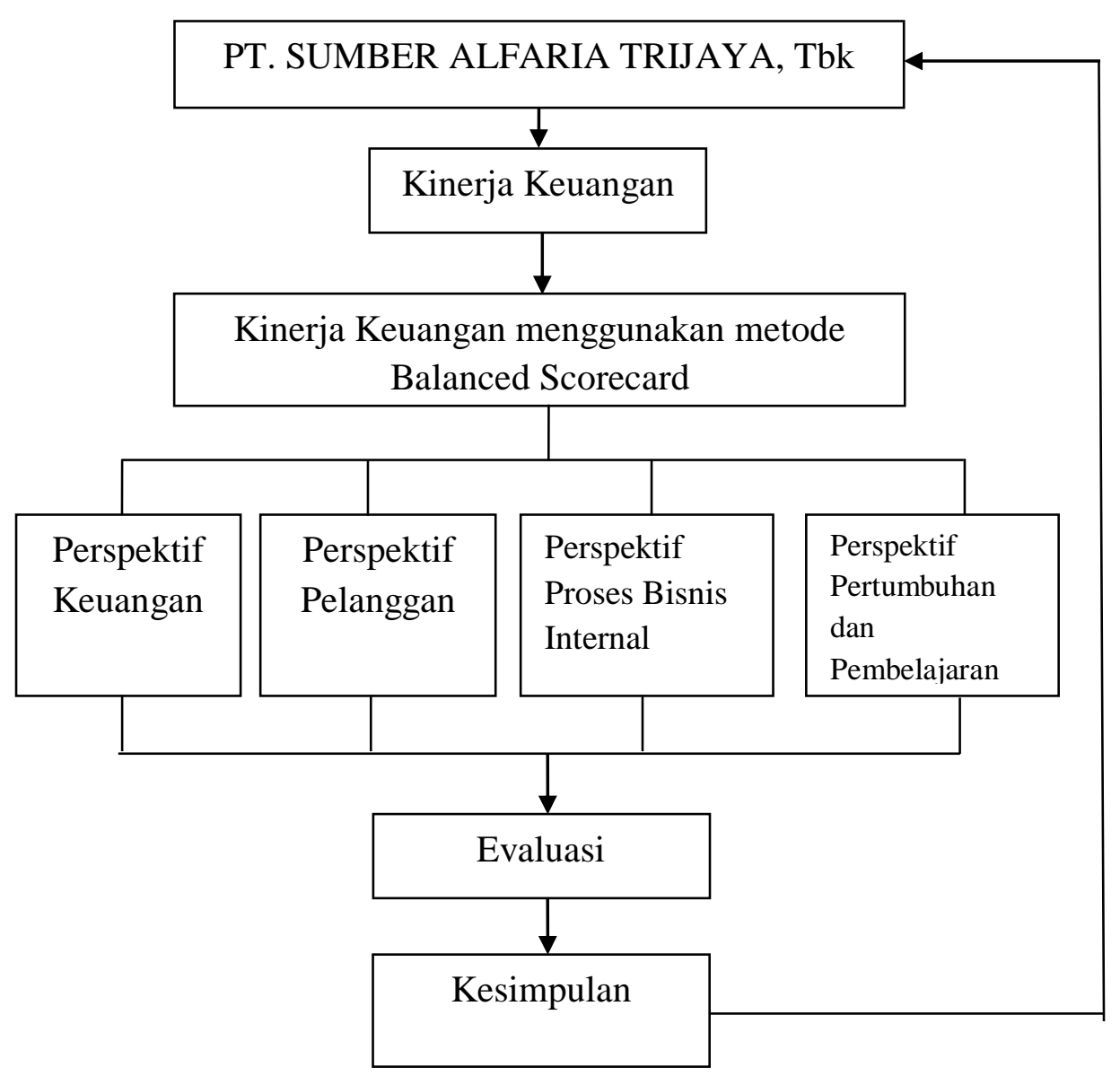

Gambar 2.1

Kerangka Pemikiran

\section{METODOLOGI PENELTIAN}

\section{A. Desain Penelitian}

Metode penelitian yang digunakan dalam penelitian ini adalah penelitian deskriptif dimana penelitian ini dilakukan untuk mengetahui nilai variabel mandiri, baik satu variabel atau lebih (independen) tanpa 
membuat perbandingan, atau menghubungkan dengan variabel lain dan jenis penelitiannya kuantitatif yaitu dengan memperoleh data dalam bentuk angka atau data kualitatif yang diangkakan.(Sugiono, 2016:11).

\section{B. Populasi dan Sampel Penelitian}

Memurut Sugiyono (2014: 61), populasi adalah wilayah generalisasi yang terdiri atas obyek/subyek yang mempunyai kualitas dan karakteristik tertentu yang ditetapkan oleh peneliti untuk dipelajari dan kemudian ditarik kesimpulannya. Populasi dalam penelitian ini adalah Laporan Keuangan PT PT. Sumber Alfaria Trijaya Tbk tahun 2013 sampai tahun 2017. Teknik pengambilan sampel yang digunakan adalah sampling jenuh. Menurut Sugiyono (2014: 68), bahwa: “teknik sampling jenuh merupakan teknik penentuan sampel bila semua anggota populasi digunakan sebagai sampel.

\section{Metode Analisis Data}

Penelitian ini menggunakan data kuantitatif, dimana data diambil berupa angka. Pada penelitian ini masing-masing perspektif dalam Balanced Scorecard akan diukur dengan indikator pengukuran kinerja yang berbeda-beda. Analisis yang digunakan dalam mengukur keempat perspektif dalam Balanced Scorecard, yaitu:

1. Perspektif keuangan dengan menggunakan Return On Assets (ROA), yaitu rasio untuk mengukur kinerja operasi yang menunjukan sejauh mana aktiva digunakan untuk operasi perusahaan untuk menghasilkan keuntunga

ROA $=\frac{\text { Laba bersih setelah pajak }}{\text { total aktiva }} \times 100 \%$

Nilai ROA disimpulkan masuk dalam kriteria baik apabila lebih besar dari $7 \%$, masuk kriteria sedang apabila sama dengan $7 \%$ dan buruk apabila kurang dari $7 \%$.

2. Perspektif pelanggan menggunakan tingkat profitabilitas 
Profitabilitas pelanggan sebuah pendekatan manajemen biaya yang mengidentifikasi biaya dan manfaat melayani pelanggan individu atau kelompok pelanggan untuk meningkatkan profit perusahaan secara keseluruhan.

Tingkat Profitabilitas Pelanggan $=\frac{\text { Laba Bersih }}{\text { Pendapatan Bersih }} \times 100 \%$

Tingkat profitabilitas pelanggan dinilai baik apabila mengalami peningkatan, dinilai sedang apabila konstan dan dinilai buruk apabila mengalami penurunan selama periode penelitian. Kriteria tersebut dapat dilihat pada ringkasan tabel kriteria:

3. perspektif proses bisnis internal

Efisiensi dapat didefinisikan sebagai perbandingan antara input dan output. Dalam hal ini, perusahaan diharapkan dapat memaksimalkan output dengan input yang dimiliki perusahaan tersebut untuk mencapai laba yang diinginkan.

Efisiensi biaya operasional $=\frac{\text { Beban Operasi }}{\text { Pendapatan Operasi }} \times 100 \%$

Tingkat efisiensi biaya operasional dinilai baik apabila mengalami penurunan, dinilai sedang apabila konstan dan dinilai buruk apabila mengalami kenaikan selama periode penelitian.

4. perspektif pembelajaran dan pertumbuhan. Produktivitas karyawan dapat diketahui dengan cara membandingkan keuntungan jasa dengan jumlah karyawan yang dimiliki perusahaan dalam periode waktu tertentu.

$$
\text { Produktifitas Karyawan }=\frac{\text { Laba bersih }}{\text { Jumlah Karyawan }} \times 100 \%
$$

Tingkat produktivitas karyawan dinilai baik apabila mengalami peningkatan, dinilai sedang apabila konstan dan dinilai buruk apabila mengalami penurunan selama periode penelitian 


\section{HASIL DAN PEMBAHASAN}

Penelitian ini membahas tentang Balanced Scorecard yang berkaitan dengan kinerja keuangan perusahaan. Evaluasi yang digunakan dalam mengukur keempat perspektif dalam Balanced Scorecard, yaitu: perspektif keuangan, perspektif pelanggan, perspektif proses bisnis internal, dan perspektif pembelajaran dan pertumbuhan. Keempat perspektif dalam Balanced Scorecard tersebut penulis gunakan untuk mengetahui kinerja keuangan perusahaan pada PT. Sumber Alfaria Trijaya, Tbk.

\section{Perspektif Keuangan}

Return On Assets (ROA) adalah rasio untuk mengukur kinerja operasi yang menunjukan sejauh mana aktiva digunakan untuk operasi perusahaan untuk menghasilkan keuntungan.

ROA

$$
=\frac{\text { Laba bersih setelah pajak }}{\text { total aktiva }} \times 100 \%
$$

ROA untuk tahun $2013=\frac{569.042}{10.962 .227} \times 100 \%=0,052$

ROA untuk tahun $2014=\frac{535.735}{13.989 .045} \times 100 \%=0,038$

ROA untuk tahun $2015=\frac{475.252}{15.195 .887} \times 100 \%=0,031$

ROA untuk tahun $2016=\frac{531.266}{19.474 .367} \times 100 \%=0,027$

ROA untuk tahun $2017=\frac{115.498}{21.901 .740} \times 100 \%=0,005$

Jika dilihat dari Return On Assets (ROA) dari tahun 2013 sampai dengan 2017, terlihat bahwa aktiva yang digunakan untuk operasi perusahaan mengalami penurunan pada tiap tahunnya, untuk lebih jelasnya dapat dilihat pada tabel dan grafik dibawah ini. 
TABEL 4.1

Return On Assets (ROA) Tahun 2013-2017

\begin{tabular}{|c|c|c|c|c|c|}
\hline \multirow{2}{*}{ Ukuran } & \multicolumn{5}{|c|}{ Tahun } \\
\cline { 2 - 6 } & $\mathbf{2 0 1 3}$ & $\mathbf{2 0 1 4}$ & $\mathbf{2 0 1 5}$ & $\mathbf{2 0 1 6}$ & $\mathbf{2 0 1 7}$ \\
\hline ROA & 0,052 & 0,038 & 0,031 & 0,027 & 0,005 \\
\hline
\end{tabular}
penulis.

\section{GRAFIK 4.1}

Grafik Return On Assets (ROA)Tahun 2013-2017

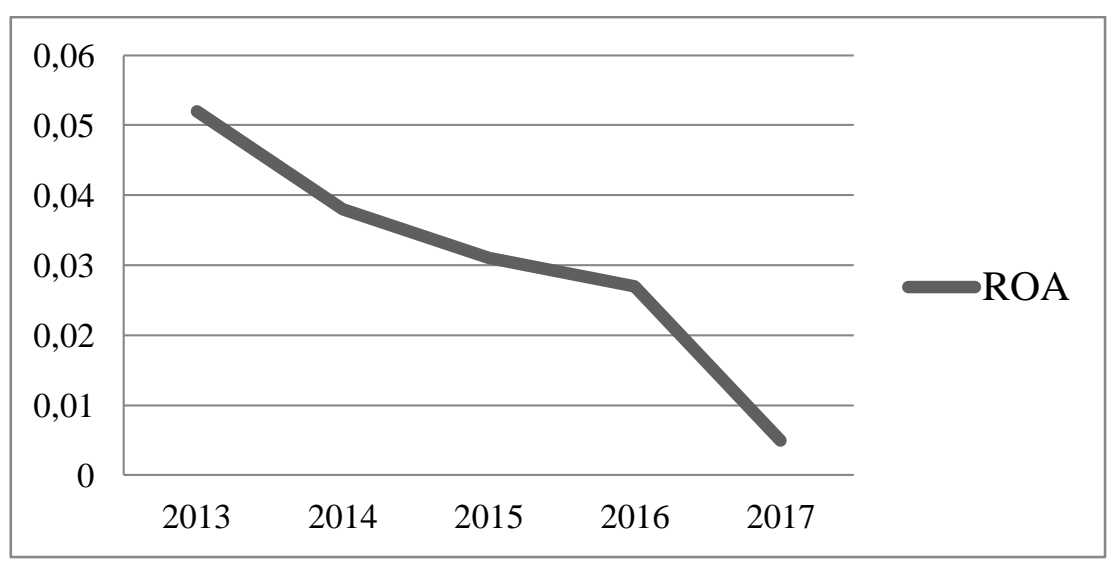

Sumber data : PT. Sumber Alfaria Trijaya, Tbk yang dioleh penulis.

Dilihat dari tabel dan grafik 4.1, terlihat bahwa adanya penurunan kemampuan perusahaan dalam menghasilkan laba dari aktiva yang digunakan disetiap tahunnya, artinya jika ROA mengalami penurunan maka tingkat keuntungan yang dicapai oleh perusahaan akan kecil dan posisi perusahaan akan kurang baik atau buruk.

\section{Perspektif Pelanggan}

Tingkat Profitabilitas Pelanggan (TPP) sebuah pendekatan manajemen biaya yang mengidentifikasi biaya dan manfaat 
melayani pelanggan individu atau kelompok pelanggan untuk meningkatkan profit perusahaan secara keseluruhan.

$$
\begin{aligned}
& \text { TPP }=\frac{\text { Laba Bersih }}{\text { Pendapatan Bersih }} \times 100 \% \\
& \text { TPP tahun 2013 }=\frac{569.042}{34.897 .259} \times 100 \%=0,016 \\
& \text { TPP tahun 2014 }=\frac{535.735}{41.495 .720} \times 100 \%=0,013 \\
& \text { TPP tahun 2015 }=\frac{475.252}{48.265 .453} \times 100 \%=0,010 \\
& \text { TPP tahun 2016 }=\frac{531.266}{56.107 .056} \times 100 \%=0,009 \\
& \text { TPP tahun 2017 }=\frac{115.498}{61.464 .903} \times 100 \%=0,002
\end{aligned}
$$

Jika dilihat dari Tingkat Profitabilitas Pelanggan dari tahun 2013 sampai dengan 2017 mengalami penurunan pada setiap tahunnya, untuk lebih jelasnya dapat dilihat pada tabel dan grafik

\section{TABEL 4.2}

Tingkat Profitabilitas Pelanggan Tahun 2013-2017

\begin{tabular}{|c|c|c|c|c|c|}
\hline \multirow{2}{*}{ Ukuran } & \multicolumn{5}{|c|}{ Tahun } \\
\cline { 2 - 6 } & $\mathbf{2 0 1 3}$ & $\mathbf{2 0 1 4}$ & $\mathbf{2 0 1 5}$ & $\mathbf{2 0 1 6}$ & $\mathbf{2 0 1 7}$ \\
\hline $\begin{array}{c}\text { TINGKAT } \\
\text { PROFITABILITAS } \\
\text { PELANGGAN }\end{array}$ & 0,016 & 0,013 & 0,010 & 0,009 & 0,002 \\
\hline
\end{tabular}

Sumber data : PT. Sumber Alfaria Trijaya, Tbk yang dioleh penulis.

\section{GRAFIK 4.2}

Tingkat Profitabilitas Pelanggan Tahun 2013-2017

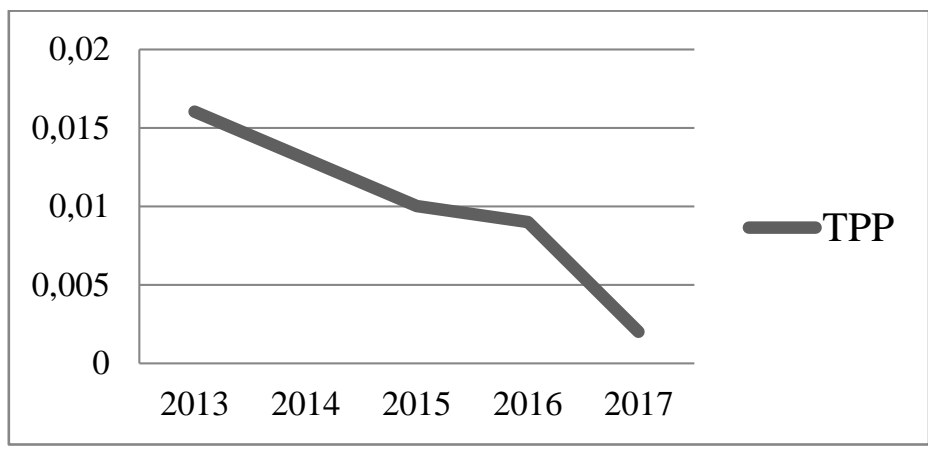

Sumber data : PT. Sumber Alfaria Trijaya, Tbk yang dioleh penulis. 
Dilihat dari tabel dan grafik 4.2, terlihat bahwa tingkat profitabilitas pelanggan pada PT Sumber Alfaria Trijaya, Tbk mengalami penurunan disetiap tahunnya. Pendapatan bersih mengalami kenaikan tiap tahunnya tetapi laba bersihnya selalu mengalami penurunan, sehingga mengakibatkan profitabilitas pelanggannya menurun.

\section{Perspektif Proses Bisnis Internal}

Efisiensi dapat didefinisikan sebagai perbandingan antara input dan output. Dalam hal ini, perusahaan diharapkan dapat memaksimalkan output dengan input yang dimiliki perusahaan tersebut untuk mencapai laba yang diinginkan.

Efisiensi biaya operasional $\quad=\frac{\text { Beban Operasi }}{\text { Pendapatan Operasi }} \times 100 \%$

Efisiensi biaya operasional $2013=\frac{20.049}{203.652} \times 100 \%=0,098$

Efisiensi biaya operasional $2014=\frac{17.856}{277.313} \times 100 \%=0,064$

Efisiensi biaya operasional $2015=\frac{15.779}{387.573} \times 100 \%=0,041$

Efisiensi biaya operasional $2016=\frac{22.834}{484.491} \times 100 \%=0,047$

Efisiensi biaya operasional $2017=\frac{19.751}{610.315} \times 100 \%=0,032$

Jika dilihat dari Tingkat Profitabilitas Pelanggan dari tahun 2013 sampai dengan 2017, terlihat bahwa efisiensi yang dilakukan perusahaan mengalami naik turun, untuk lebih jelasnya dapat dilihat pada tabel dan grafik.

TABEL 4.3

Efisiensi Biaya Operasional Tahun 2013-2017

\begin{tabular}{|c|c|c|c|c|c|}
\hline \multirow{2}{*}{ Ukuran } & \multicolumn{5}{|c|}{ Tahun } \\
\cline { 2 - 6 } & $\mathbf{2 0 1 3}$ & $\mathbf{2 0 1 4}$ & $\mathbf{2 0 1 5}$ & $\mathbf{2 0 1 6}$ & $\mathbf{2 0 1 7}$ \\
\hline $\begin{array}{c}\text { EFISIENSI } \\
\text { BIAYA } \\
\text { OPERASIONAL }\end{array}$ & 0,098 & 0,064 & 0,041 & 0,047 & 0,032 \\
\hline
\end{tabular}

Sumber data : PT. Sumber Alfaria Trijaya Tbk (BEI) yang diolah penulis. 
GRAFIK 4.3

EFISIENSI BIAYA OPERASIONAL Tahun 2013-2017

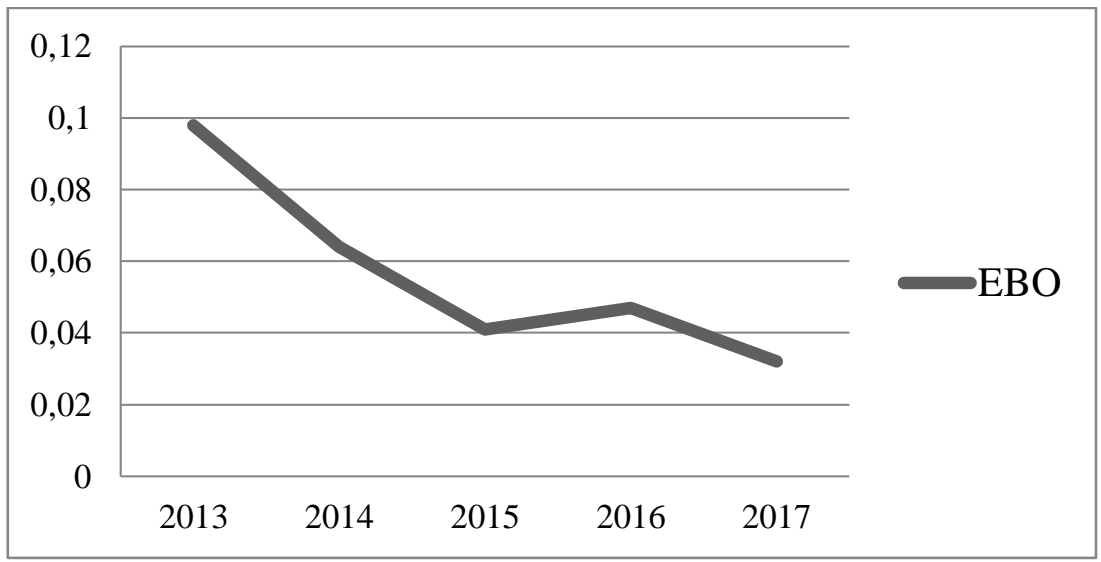

Sumber data : PT. Sumber Alfaria Trijaya Tbk (BEI) yang diolah penulis.

Dilihat dari tabel dan grafik 4.3, terlihat bahwa adanya penurunan biaya operasional. Perusahaan bisa dikatakan berhasil menekan biaya operasional, meskipun beban operasional tiap tahunnya mengalami penurunan dan kenaikan, tetapi pendapatan operasional yang naik terus berdampak pada efesiensi biaya operasional tersebut.

\section{Perspektif Pembelajaran dan Pertumbuhan}

Produktivitas karyawan dapat diketahui dengan cara membandingkan keuntungan jasa dengan jumlah karyawan yang dimiliki perusahaan dalam periode waktu tertentu.

Produktifitas Karyawan $=\frac{\text { Laba bersih }}{\text { Jumlah Karyawan tetap }} \times 100 \%$

Produktifitas Karyawan $2013=\frac{569.042}{25.718} \times 100 \%=22,1$

Produktifitas Karyawan $2014=\frac{535.735}{29.633} \times 100 \%=18,1$

Produktifitas Karyawan $2015=\frac{475.252}{37.907} \times 100 \%=12,5$

Produktifitas Karyawan $2016=\frac{531.266}{42.115} \times 100 \%=12,1$

Produktifitas Karyawan $2017=\frac{115.498}{47.310} \times 100 \%=2,4$ 
Jika dilihat dari Produktivitas Karyawan dari tahun 2013 sampai dengan 2017, terdapat kenaikan jumlah karyawan disetiap tahunnya sedangkan laba perusahan mengalami penurunan disetiap tahunnya, bisa dikatakan produktivitas karyawan PT. Sumber Alfaria Trijaya Tbk dikatakan buruk atau tidak produktif.

TABEL 4.4

PRODUKTIVITAS KARYAWAN Tahun 2013-2017

\begin{tabular}{|l|l|l|l|l|l|}
\hline \multirow{2}{*}{ Ukuran } & \multicolumn{5}{|c|}{ Tahun } \\
\cline { 2 - 6 } & 2013 & 2014 & 2015 & 2016 & 2017 \\
\hline $\begin{array}{l}\text { PRODUKTIVITAS } \\
\text { KARYAWAN }\end{array}$ & 22,1 & 18,1 & 12,5 & 12,1 & 2,4 \\
\hline
\end{tabular}

Sumber data : PT. Sumber Alfaria Trijaya Tbk (BEI) yang diolah penulis.

GRAFIK 4.4

PRODUKTIVITAS KARYWAN Tahun 2013-2017

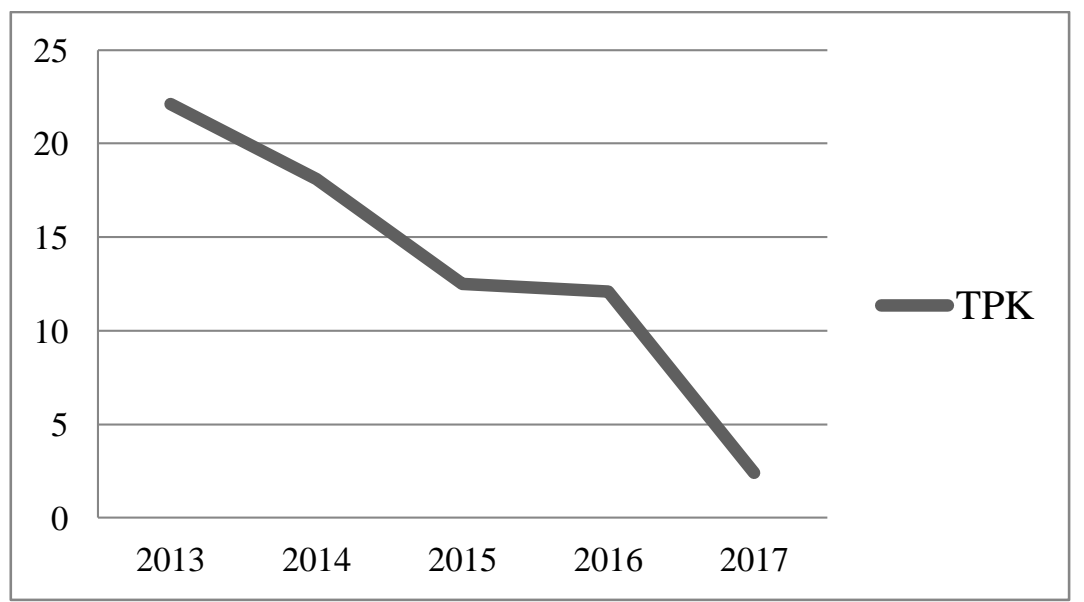

Sumber data : PT. Sumber Alfaria Trijaya Tbk (BEI) yang diolah penulis.

Dilihat dari tabel dan grafik 4.4, terlihat bahwa perusahaan selalu mengalami penurunan tingkat produktivitas karyawan disetiap tahunnya dikarenakan selalu ada kenaikan jumlah karyawan sedangkan tidak bisa diimbangi dengan kenaikan laba 
perusahan, sehingga bisa dikatakan produktivitas karyawan PT. Sumber Alfaria Trijaya Tbk tidak produktif atau buruk.

\section{Kesimpulan}

Dari hasil pembahasan, dapat ditarik kesimpulan tentang kinerja perusahaan pada tahun 2013 - 2017 pada PT. Sumber Alfaria Trijaya, Tbk sebagai berikut:

1. Perspektif Keuangan dalam hal ROA pada PT. Sumber Alfaria Trijaya Tbk dari tahun 2013 sampai dengan tahun tahun 2017 semakin menurun. Hal ini menggambarkan bahwa kemampuan perusahaan untuk menghasilkan keuntungan atas aktiva tergolong buruk.

2. Perspektif Pelanggan dalam hal tingkat profitabilitas pelanggan PT. Sumber Alfaria Trijaya Tbk dari tahun 2013 sampai dengan tahun tahun 2017 mengalami penurunan disetiap tahunnya. Hal ini menggambarkan bahwa terjadi ketidak selarasan antara Pendapatan bersih dengan laba bersih. Pendapatan bersih mengalami kenaikan tiap tahunnya tetapi laba bersihnya selalu mengalami penurunan, sehingga mengakibatkan profitabilitas pelanggannya menurun.

3. Perspektif Proses Bisnis Internal dalam hal ini efisiensi biaya operasional pelanggan PT. Sumber Alfaria Trijaya Tbk dari tahun 2013 sampai dengan tahun tahun 2017 mengalami penurunan. Hal ini menggambarkan perusahaan berhasil menekan biaya operasional, meskipun beban operasional tiap tahunnya mengalami penurunan dan kenaikan, tetapi pendapatan operasional yang naik terus berdampak pada efesiensi biaya operasional tersebut. Hal ini dapat disimbulkan bahwa perusahaan berhasil menekan biaya operasional.

4. Perspektif Pertumbuhan dan Pembelajaran dalam hal ini tongkat produktivitas karyawan PT. Sumber Alfaria Trijaya Tbk dari tahun 2013 sampai dengan tahun tahun 2017 mengalami penurunan. Terlihat bahwa perusahaan selalu mengalami penurunan tingkat produktivitas karyawan disetiap tahunnya dikarenakan selalu ada kenaikan jumlah 
karyawan sedangkan tidak bisa diimbangi dengan kenaikan laba perusahan, sehingga bisa dikatakan produktivitas karyawan PT. Sumber Alfaria Trijaya Tbk buruk.

5. Laba bersih PT. Sumber Alfaria Trijaya Tbk dari tahun 2013 sampai dengan tahun tahun 2017 mengalami fluktuasi tetapi kinerja keuangan perusahaan dapat dikatakan baik karena terdapat kenaikan.

\section{Referensi}

Anthony \& Govindrajan, 1997. "Management Control System".

Anthony dan Govindrajan, 2005. "Management Control System", Edisi Pertama, Penerbit Salemba Empat. Jakarta.

Dadang Dally, 2010. “Balanced Scorecard Suatu Pendekatan Dalam Implementasi Manajemen Berbasis Sekolah". Bandung: PT Remaja Rosda Karya.

Fahmi, Irham. 2011. “ Analisis Laporan Keuangan”. Lampulo: ALFABETA.

Hubert K Rampersad, 2006. "Personal Balanced Scorecard The Way to Individual Happiness, Personal Integrity and Organizationak Effectiveness".

Hubert K Rampersad, 2006. "Personal Balanced Scorecard Sinergikan Ambisi Pribadi Anda dengan Ambisi Perusahaan", Terjemahan: Widya dan Abdul Rosyid. Penerbit PPM. Jakarta.

Ikatan Akuntan Indonesia, 2007. Standar Akuntansi Keuangan. Penerbit Salemba Empat. Jakarta.

Jumingan. 2006. “Analisis Laporan Keuangan, Cetakan Pertama”, PT Bumi Aksara, Jakarta.

Kaplan, Robert S. \& David P. Norton, 1996. "The Balanced Scorecard: translating strategy into action. Massachusetts: Harvard Business School Press." 
Kaplan, Robert S. \& David P. Norton, 2000. “Balanced Scorecard: Menerapkan Strategi Menjadi Aksi", Terjemahan: Pasla Yosi Peter R. Penerbit Erlangga. Jakarta.

Mulyadi, 2007. "Sistem Manajemen Strategik Berbasis Balanced Scorecard". Yogyakarta : UPP AMP YKPN.

Mulyadi, 2007. "Balanced Scorecard : Alat Manajemen Kontemporer Untuk Pelipatgandaan Kinerja Keuangan Perusahaan", Edisi kelima. Penerbit Salemba Empat. Jakarta.

Mulyadi, 1997. "Akuntansi Manajemen: Konsep, Manfaat dan Rekayasa". Edisi 8. STIE-YKPN. Yogyakarta.

Munawir, S, 2012. “Analisis Informasi Keuangan". Penerbit Liberty. Yogyakarta.

Sugiono, 2014. "Metode Penelitian Bisnis". Penerbit Pusat Bahasa Depdiknas. Bandung.

Sugiyono, 2011. "Metode Penelitian Kuantitatif, Kualitatif, dan RED". Penerbit Alfabeta. Bandung.

Soemarso, 2004. "Akuntansi Suatu Pengantar", Edisi kelima. Penerbit Salemba Empat. Jakarta.

Sucipto, 2003. "Penilaian Kinerja Keuangan". Jurnal Akuntansi, Program Sarjana Universitas Sumatera Utara, Medan.

Situs online

http://yes-sejarah.blogspot.com/2017/05/sejarah-dan-profil-pt-sumber-alfaria.html

http://corporate.alfamartku.com/struktur-organisasi-alfamart

https://id.wikipedia.org/wiki/Alfamart

http://erwinpurwindiyanto.blogspot.co.id/2012/12/pt-sumber-alfaria-trijaya-tbk.html

http://corporate.alfamartku.com/struktur-organisasi-alfamart 